\title{
Editorial
}

\section{Effects after acute and chronic exposure to cotton dust: the Manchester criteria}

It has been known for many years that people exposed to dust from cotton, flax, or soft hemp may develop a characteristic feeling of chest tightness on Mondays accompanied by an impairment of respiratory function. This reaction is classically referred to as "byssinosis" 1 and has been used as a criterion to improve the working conditions in cotton mills and for compensation.

After large studies on populations exposed to cotton dust and to other dusts of vegetable origin, it has become apparent that other reactions may also be present which do not fit the traditional description of byssinosis. The introduction of additional terms such as "acute byssinosis," "atypical byssinosis," or "bronchitis byssinosis" has created confusion.

An attempt to clarify the situation was made recently during a meeting of researchers who have an extensive knowledge of pulmonary reactions after exposure to cotton dust. The meeting took place in Manchester, UK, on 3 November 1986. The initiative was taken by the committee for organic dusts at the International Commission on Occupational Health (ICOH). The procedure was adapted to describe the reactions known to occur after exposure to cotton dust and to establish research goals. This editorial reports the conclusions reached at the meeting.

\section{Reactions after exposure to cotton dust}

\section{MILL FEVER}

An acute fever with influenza like symptoms may develop in the afternoon or evening on the first occasion of exposure to cotton dust. These symptoms occur in various environments where vegetable or other organic dusts are found, when handling grain, and when working in swine confinement buildings. The term "organic dust toxic syndrome (ODTS)" has recently been suggested. ${ }^{2}$

The development of fever after exposure to cotton dust is related to relatively high exposure levels and the reaction is rare in modern cotton mills with efficient dust control. The fever is not present after repeated exposures (tolerance) but it may recur after a prolonged absence from work or after a heavy exposure. There is no information on the relation between the susceptibility to develop fever and the risk of effects that develop after long term exposure.
PULMONARY FUNCTION

Several types of change in pulmonary function may develop after exposure to cotton dust. Some information is available on changes in respiratory pattern; exposure to cotton dust may induce more rapid and shallow breathing that is accentuated after exposure to $\mathrm{CO}_{2}{ }^{3}$

A well documented change is the gradual decrease over the working day in airway flow, caused by bronchoconstriction and reversible with salbutamol. This effect is usually determined by measuring the forced expiratory flow in one second $\left(\mathrm{FEV}_{1}\right)$.

This reduction in air flow may be provoked in people previously unexposed to cotton dust. The reaction in cotton workers is most pronounced on the first day after a break in work. It is not clear whether the magnitude of the response increases with increasing number of years in the mill; smokers do, however, present a more pronounced reaction. ${ }^{4}$

Regarding changes over time, prospective studies of active and retired cotton workers with and without symptoms of Monday chest tightness show a greater than expected annual decline in baseline FEV ${ }_{1}{ }^{5}$

There is no information on the relation between the magnitude of the acute bronchoconstriction over the workshift and a greater risk of decline in baseline $\mathrm{FEV}_{1}$ after long term exposure.

In a small proportion of cotton workers (less than $1 \%)$ pulmonary function may decrease within half an hour of starting work. This increases in severity over the working week and probably represents a form of occupational asthma. Usually those experiencing this type of response are forced to leave the industry at an early stage.

\section{CHEST TIGHTNESS}

A subjective feeling of tightness in the chest, which slowly develops on the afternoon of the first day of the working week, is a characteristic feature of a long term exposure to cotton dust. ${ }^{1}$ This symptom usually takes several years to develop but may be provoked acutely by high dust exposure. ${ }^{4}$ Over a period, chest tightness may develop more rapidly during the first half of the working shift. There is no certain information if this symptom is worse in smokers.

Although chest tightness and bronchoconstriction often occur together, they may also occur 
independently of one another. ${ }^{46}$

A few workers may experience chest tightness on all days during the week; the severity may also increase over the week. These workers also have the bronchoconstriction described above (occupational asthma).

\section{HYPERREACTIVE AIRWAYS}

An increase in the reactivity of the airways, for example, to methacholine may be present after an acute exposure to cotton dust (B Boehleke et al, presented at 3rd International conference on environmental lung disease, Montreal, 1986). This hyperreactivity is also present in workers with repeated exposures. ${ }^{7}$ Although the data are incomplete, observations suggest that the presence of hyperreactive airways may be an important factor in determining the development of disability after exposure to cotton dust. Bronchial hyperreactivity may be present several years after the cessation of exposure to cotton dust and the resolution of the symptom of chest tightness.

\section{CHRONIC BRONCHITIS}

After a prolonged exposure, particularly to high dust concentrations, some of the working population may develop chronic bronchitis with cough and sputum. The symptoms are most commonly found among smokers but may also be present among non-smokers. On the other hand, a large proportion of workers regularly suffering from chest tightness on Mondays have a dry cough without sputum. The interaction with smoking has not been studied.

\section{Disability effects}

There are conflicting data concerning increased mortality due to pulmonary or cardiovascular disease among cotton workers, although an increased risk was demonstrable at high exposure levels in the past. This increase in mortality has not been shown at current low exposure levels.

Some studies suggest that an air flow limitation may persist several years after the cessation of exposure. ${ }^{8}$ A possible mechanism for this effect is a persistent airway hyperreactivity, which renders the subjects susceptible to everyday airborne triggers for bronchoconstriction such as smoke and dust or cold air.

\section{Priorities for research}

\section{BACKGROUND}

Enough information is available to characterise the acute and the chronic symptoms that follow exposure to high dust concentrations. Work is advanced con- cerning the causative agents and dose-response relations have been presented between the acute responses and the amount of bacterial endotoxin the dust. No expansion of the present research effor $\overrightarrow{\vec{X}}$ in these areas seems justified.

The present situation in cotton mills is characte ised by progressively lower dust concentrations, pa ticularly in the United States where cases of class byssinosis (chest tightness on Mondays) are now rarely seen. As a result of this, workers particularly susceptible to cotton dust exposure such as those wit hyperreactive airways may now no longer select themselves out of the industry at an early stage. The risk of developing disease in this group after long term exposure to low doses is not known. It is also unclea? how the development of hyperreactive airways relates to life expectancy or disablement.

\section{RESEARCH NEEDS}

There is a need to evaluate the relation between acute effects on the first exposure or over the workshift to. the risk of long term effects. The only means of obtaines ing such information is to perform longitudinal stu\& ies, where those starting work in the mills are screened for airway reactivity, the presence of symptoms after an acute exposure, and atopy. These workers need to be followed up on a regular basis. For those who leave the industry, which in some industrial population up to a third of the workforce, the reasons, particularly if related to adverse pulmonary reactions, shoila be documented. After a 5-10 year follow up, particts larly of workers in dusty environments, it should be possible to answer some of the above questions corp cerning the relation between acute symptoms and chronic effects. This should make more effective prë vention possible. The results will also be applicable to other environments with exposure to organic dusts?

RYLANDER

Department of Environmental Hygiene, University \&f Gothenburg, Sweden.

11C Prior Bolton Street, London UK RSF SCHILLINOS

CAC PICKERINQ

Department of Chest Medicine, University of Ma chester, Manchester, UK.

GB ROOKg AN DEMPSEY

Medical Boarding Centre (Respiratory Diseases Manchester, UK.

RR JACO $\frac{0}{\mathrm{KSS}}$

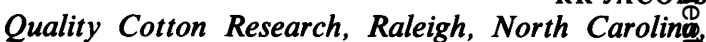
USA. 


\section{References}

1 Schilling RSF, Hughes JPW, Dingwall-Fordyce I, Gilson JC. An epidemiological study of byssinosis among Lancashire cotton workers. B J Ind Med 1955;12:217-27.

2 Do Pico G. Health effects of organic dusts in the farm environment. Report on diseases. Am J Ind Med 1986;10:261-5.

3 Prausnitz C. Investigations on respiratory dust disease in operatives in cotton industry. London: Medical Research Council, 1936. (Special report series, No 212.)

4 Haglind P, Rylander R. Exposure to cotton dust in an experimental cardroom. Br J Ind Med 1984;10:340-5.

5 Rooke GB, Dempsey AN, Hillier VF, Jeacock J. Further observations on byssinotics diagnosed in the United Kingdom. In:
Jacobs RR, Wakelyn PJ, eds. Proceedings of the 1lth cotton dust research conference, Beltwide Cotton Research Conference, Dallas, Texas, 1987. Memphis TN: National Cotton Council, 1987.

6 Berry G, McKerrow CB, Molyneux MKB, Rossiter CE, Tombleson JBL. A study on the acute and chronic changes in ventilatory capacity of workers in Lancashire cotton mills. Br J Ind Med 1973;30:25-36.

7 Haglind P, Bake B, Belin L. Is mild byssinosis associated with small airways disease? Eur J Respir Dis 1983;64:449-59.

8 Beck GH, Maunder LR, Schachter EN. Cotton dust and smoking effects on lung function in cotton textile workers. Am J Epidemiol 1984;119:33-43.

\section{Correspondence and editorials}

The British Journal of Industrial Medicine welcomes correspondence relating to any of the material appearing in the journal. Results from preliminary or small scale studies may also be published in the correspondence column if this seems appropriate. Letters should be not more than 500 words in length and contain a minimum of references. Tables and figures should be kept to an absolute minimum. Letters are accepted on the understanding that they may be subject to editorial revision and shortening.

The journal now also publishes editorials which are normally specially commissioned. The Editor welcomes suggestions regarding suitable topics; those wishing to submit an editorial, however, should do so only after discussion with the Editor. 